\section{Yield and composition of milk from Lusitano lactating mares}

\author{
Ana Sophia Santos', Bárbara C. Sousa, Luisa C. Leitão² \\ and Virgílio C. Alves ${ }^{3}$
}

Department of Veterinary, Esc. Univ. Vasco da Gama, Quinta de S. Jorge, Castelo Viegas, Coimbra' ${ }^{1}$, Department of Animal Science, Esc. Sup. Agrária de Coimbra, Bencanta ${ }^{2}$ and CECAV - Department of Animal Science, Univ. de Trás-os-Montes e Alto Douro 3 Portugal

\section{Introduction}

A better understanding of the nutrient requirements for both mare and foal requires the knowledge of mare's milk production and composition. Although information on mare's milk composition is somewhat extensive (Doreau et al. 1990), the information regarding milk yield is scarce, probably due to methodology limitations (Doreau and Boulot 1989). However some information regarding milk yield and its composition is available, no information on the Lusitano breed was found. The Lusitano horse is used all over the world and it plays an important role in equine production in Portugal. With a production system based on roughage availability, the young foals depend almost exclusively, and for a long period of time, on their mother's milk, revealing the importance of available accurate information on this matter.

The aim of this study was to evaluate the yield and composition of milk from Lusitano mares and it's evolution on the first 120 days of lactation.

\section{Material and methods}

Seven multiparous nursing Lusitano mares aged 7 to 12 years, with an average live weight after foaling of $472.1 \pm 36 \mathrm{~kg}$, were used in this study. The mares were grazing during the day, in a ryegrass pasture (17.4\% crude protein), and were kept indoors during the night. A supplement of $2 \mathrm{~kg}$ of concentrate $(14.5 \% \mathrm{CP})$ and $3 \mathrm{~kg}$ of hay $(10.8 \% \mathrm{CP})$ was individually offered twice a day (before and after the grazing period).

Milk yield and composition was evaluated on days 15, 45, 60, 90 and 120 post-partum. The procedures followed were: a) Separation of mare and foal for 1 hour. Mare and foal where able to see, touch and smell each other, but the foal was not able to suck. b) Administration of $1.0 \mathrm{ml}$ of an oxitocin solution $(20 \mathrm{lU} / \mathrm{ml})$ to the mare followed by hand-milking of the two teats as deep as possible, this was made in the presence of the foal. The foal was left to suckle, and since the efforts of the foal were unsuccessful, the udder was assumed to be empty. The milk collected was then given to the foal. c) Second mare-foal separation, that was identical to the first. d) Oxitocin administration and milking identical to the procedure. b) The amount of milk collected was measured and a $200 \mathrm{ml}$ sample was withdrawn. The remaining milk was offered to the foal.

Additionally milk composition was also measured on days 30, 75 and 105 post-partum, the previous a) and b) procedures were also fallowed except for the oxitocin administration.

Each milk sample was prepared for chemical analyses according to current procedures. Fat determination (Gerber method); Kjeldahl-N; lactose (infrared spectrophotometry on a milko scan analiser); calcium, potassium and magnesium (atomic absorption spectrophotometry) were determined according to standard procedures.

\section{Results}

Average values of milk yield and composition are presented in Table 1. Average daily milk production increased from $13.3 \mathrm{~kg}$ on day 15 to $14.2 \mathrm{~kg}$ on day 45 and then decreased, reaching $10.5 \mathrm{~kg}$ on day 120 of lactation. The higher milk yield occurred at day $45(14.2 \pm 2.3 \mathrm{~kg})$, and represented $3 \%$ of live weight.

Total solids ranged from 92.5 to $82.3 \mathrm{~g} / \mathrm{kg}$, averaged 88.1 $\mathrm{g} / \mathrm{kg}$ and showed a tendency to decrease $(P>0.05)$ throughout the lactation curve. Milk protein values ranged from 22.7 to $14.9 \mathrm{~g} / \mathrm{kg}$ with an averaged of $18.5 \mathrm{~g} / \mathrm{kg}$ and followed the same tendency as total solids, but in the first 30 days was significantly higher $(P<0.05)$ then in the last observed 15 days of the lactation curve. Fat also tended to decrease from day 15 to day 120 and averaged $5.9 \mathrm{~g} / \mathrm{kg}$ and exhibit significantly higher values in the beginning then in the end of the lactation curve. Lactose content in milk showed an inverse, but not significant, trend, and increased $(P>0.05)$ from day 15 to day 105 (54.5 and $67.1 \mathrm{~g} / \mathrm{kg}$ ) the average value was $60.84 \mathrm{~g} / \mathrm{kg}$. Total ashes and calcium, potassium and magnesium contents of milk showed a tendency $(P>0.05)$ to decrease throughout lactation curve.
Table 1 Milk nutrient composition and production (mean and standard deviation) from lactating mares

\begin{tabular}{|c|c|c|c|c|c|c|c|c|}
\hline & \multicolumn{8}{|c|}{ Days of lactation } \\
\hline & 15 & 30 & 45 & 60 & $\begin{array}{l}75 \\
\end{array}$ & 90 & 105 & 120 \\
\hline \multicolumn{9}{|l|}{ Milk composition: } \\
\hline Total solids $\mathrm{g} / \mathrm{kg}$ & $92.5 \pm 6.6$ & $90.4 \pm 3.9$ & $88.1 \pm 2.5$ & $89.8 \pm 1.9$ & $88.3 \pm 1.9$ & $87.9 \pm 10.9$ & $82.3 \pm 7.5$ & $85.8 \pm 1.3$ \\
\hline Ashes $\mathrm{g} / \mathrm{kg}$ & $4.86 \pm 0.84$ & $4.77 \pm 0.19$ & $3.98 \pm 0.46$ & $3.88 \pm 0.51$ & $4.04 \pm 0.55$ & $3.3 \pm 0.35$ & $3.57 \pm 0.74$ & $3.52 \pm 0.43$ \\
\hline Fat $\mathrm{g} / \mathrm{kg}$ & $10.5^{c} \pm 4.0$ & $7.55^{\mathrm{cb}} \pm 1.95$ & $5.47^{b a} \pm 0.67$ & $6.11^{c b a} \pm 2.12$ & $5.24^{\mathrm{b} a} \pm 1.74$ & $5.43^{b a} \pm 2.08$ & $3.81^{\circ} \pm 2.11$ & $4.51^{\mathrm{bo}} \pm 1.96$ \\
\hline Protein $\mathrm{g} / \mathrm{kg}$ & $22.7^{b} \pm 4.8$ & $22.2^{b} \pm 3.4$ & $17.9^{a b} \pm 2.2$ & $17.8^{a b} \pm 2.7$ & $18.1^{a b} \pm 2.0$ & $17.8^{a b} \pm 4.0$ & $16.0^{\circ} \pm 4.0$ & $14.9^{\circ} \pm 1.2$ \\
\hline Lactose $\mathrm{g} / \mathrm{kg}$ & $54.5 \pm 6.6$ & $55.5 \pm 4.5$ & $60.7 \pm 1.4$ & $62.0 \pm 2.1$ & $60.9 \pm 1.7$ & $64.7 \pm 3.6$ & $67.1 \pm 5.7$ & $65.1 \pm 2.9$ \\
\hline \multicolumn{9}{|l|}{ Minerals $\mathrm{mg} / 100 \mathrm{~g}$} \\
\hline $\mathrm{Ca}$ & $112.4 \pm 8.4$ & $114.7 \pm 0.10$ & $96.2 \pm 0.17$ & $87.3 \pm 0.13$ & $92.1 \pm 0.15$ & $77.9 \pm 0.14$ & $70.1 \pm 0.15$ & $62.0 \pm 0.12$ \\
\hline K & $57.3 \pm 0.01$ & $51.76 \pm 0.01$ & $41.5 \pm 0.01$ & $39.9 \pm 0.01$ & $45.1 \pm 0.01$ & $30.6 \pm 0.01$ & $35.8 \pm 0.01$ & $31.5 \pm 0.01$ \\
\hline $\mathrm{Mg}$ & $6.69 \pm 0.09$ & $6.68 \pm 0.04$ & $5.35 \pm 0.06$ & $4.88 \pm 0.06$ & $5.69 \pm 0.08$ & $3.32 \pm 0.07$ & $3.80 \pm 0.08$ & $3.38 \pm 0.05$ \\
\hline \multicolumn{9}{|l|}{ Daily milk yield } \\
\hline $\mathrm{Kg} /$ day & $13.1^{b} \pm 1.5$ & - & $14.2^{b} \pm 2.3$ & $12.9^{b} \pm 1.8$ & - & $11.1^{\circ} \pm 2.1$ & - & $10.7^{a} \pm 1.2$ \\
\hline $\mathrm{kg} / 100 \mathrm{~kg} \mathrm{LW}^{1}$ & $2.80 \pm 0.45$ & - & $3.01 \pm 0.53$ & $2.72 \pm 0.29$ & - & $2.35 \pm 0.39$ & - & $2.27 \pm 0.33$ \\
\hline
\end{tabular}




\section{Discussion}

The results obtained for milk yield, varying from $14.2 \mathrm{~kg}$ at day 45 ( $3 \%$ body weight) to $10.7 \mathrm{~kg}(2.27 \%$ body weight), are in accordance to the data reported by NRC (1989) and to the results obtained for other light breeds such as Thoroughbred, French saddle and Anglo-arab (Oftedal et al. 1983, Doreau et al. 1993), and for Quarter horse mares (Gibbs et al. 1982). In spite of higher values being mentioned for heavy mares, such as Percheron and Breton, the milk yield values herein presented are comparable to majority of data available in the literature (Doreau and Boulot 1989).

Regarding milk composition, both protein and fat concentrations decreased along the lactation period. Protein average value $(18.5 \mathrm{~g} / \mathrm{kg})$ is lower than the average content calculated from the data presented by Oftedal et al. (1983) - 20 $\mathrm{g} / \mathrm{kg}$; and higher than the one reported by Kücükcetin et al. (2003) - $16 \mathrm{~g} / \mathrm{kg}$; and are within the general reference values given by Doreau and Boulot (1989).

As expected, fat concentrations were low because mare's milk is very poor in fat (Doreau and Boulot 1989). The average fat content $(5.9 \mathrm{~g} / \mathrm{kg})$ obtained is lower than the values reported by Csapó et al. (1995) and Kücükcetin et al. (2003), 12.5 $\mathrm{g} / \mathrm{kg}$ and $10 \mathrm{~g} / \mathrm{kg}$, respectively.

With an average value of $60.84 \mathrm{~g} / \mathrm{kg}$, lactose content in milk slightly increased during lactation. Pagan and Hintz (1986), in a study conducted with pony mares reported an average value of $66 \mathrm{~g} / \mathrm{kg}$. Following the same trend, Smolders et al., 1990 refer an average content of $62 \mathrm{~g} / \mathrm{kg}$, in light breed mares.

Mineral and ash content are very similar to the results of Summer et al. (2004). These authors, using Haflinger mare's milk, report an average ash content of $3.7 \mathrm{~g} / \mathrm{kg}$, and $\mathrm{Ca}, \mathrm{K}$ and $\mathrm{Mg}$ contents of $77.9,48.3$ and $6.5 \mathrm{mg} / 100 \mathrm{~g}$, respectively.

\section{Conclusions}

To the extent of our knowledge, there are no published results on milk yield and composition for Lusitano mares. Although the experimental period for milk yield measurements did not include data prior to $15 \mathrm{~d}$ days post-partum, we can verify that the maximum milk production occurs on the first 2 months of lactation. This information is important to properly feed mares, maximizing milk production and its intake by foals.
Moreover, positive consequences on the improvement of the Lusitano Breed will be achieved if these results are accounted for when planning foaling dates.

\section{References}

Csapó J., Stefler J., Martin T. G., Makrey S. and Csapó-Kiss Z. (1995): Composition of mare's colostrums and milk. Fat content, fatty acid composition and vitamin content. International Dairy Journal 5, 393-402

Doreau M. and Boulet S. (1989): Recent knowledge on mare milk production: a review. Livestock Production Science 22, 213-235

Doreau M., Boulot S., Barlet J. P. and Patureau-Mirand P. (1990): Yield and composition of milk from lactating mares: effect of lactation stage and individual differences. Journal of Dairy Research 57, 449-454

Doreau M., Boulot S. and Chilliard Y. (1993): Yield and composition of milk from lactating mares: effect of body condition at foaling. Journal of Dairy Research 60, 457-466

Gibbs P., Potter G. D., Blake R. W. and McMullan W. C. (1982): Milk production of quarter horse mares during 150 days of lactation. Journal of Animal Science 54, 496-499

Kücükcetin A., Yaygin H., Hinrichs J. und Kulozik U. (2003): Adaptation of bovine milk towards mare's milk composition by means of membrane technology for koumiss manufacture. International Dairy Journal 13, 945-951

National Research Council (NRC). Nutrient Requirements of Domestic Animals. $\mathrm{n}^{\circ} 6$ Nutrient Requirements of Horses, 5th revised edition. National Academy of Sciences, Washington D.C. 1989

Oftedal O. T., Hintz H. F. and Schryver H. F. (1983): Lactation in the horse: milk composition and intake by foals. Journal of Nutrition 113, 2196-2206

Pagan J. D. and Hintz H. F. (1986): Composition of milk from pony mares fed various levels of digestible energy. Equine Vet J 16, 263

Smolders E. A. A., van der Veen N. E. and van Polanem A. (1990): Composition of horse milk during the sucling period. Livestock Production Science 25, 163-171

Summer A., Sabbioni A., Formaggioni P. and Mariani P. (2004): Trend in ash and mineral element content of milk from Haflinger nursing mares throughout six lactation months. Livestock Production Science 88, 55-62 